\title{
Detection of Escherichia Coli hlyA gene and Staphylococcus aureus Sea gene in raw milk of buffaloes using RT-PCR technique in AL- Qadisiyah province
}

\author{
J.N. Sadeq ${ }^{*}$, Kh.H. Fahed and H.J. Hassan \\ College of Veterinary Medicine, University of Al-Qadisiyah, Al-Qadisiyah, Iraq, "Email: jinan.sadeq@qu.edu.iq
}

(Received October 13, 2017; Accepted December 23, 2017)

\begin{abstract}
The aim of this study was to determines the prevalence of virulence gene hemolysin A (hly A) Escherichia coli and staphylococcal enterotoxins (sea) in Staphylococcus aureus in raw milk buffaloes. In molecular laboratory, real-time polymerase chain reaction (RT-PCR) technique has been performed for 24 samples which have been taken randomly from Buffaloes milk, using primers of high specificity for Escherichia coli hlyA gene and Staphylococcus aureus Sea genes. The results showed different degrees of the studied genes activities. Four out of 24 samples represented S. aureus Sea gene (16.6\%) whereas 16 out of 24 samples represented E. coli hlyA gene (66.6\%). this study concluded that buffaloes milk might be a source of contamination with pathogenic bacteria of virulent genes which may have different levels of activities
\end{abstract}

Keywords: Real-Time Polymerase Chain Reaction, Escherichia Coli, hlyA gene, Staphylococcus aureus, Sea gene Available online at http://www.vetmedmosul.org/ijvs

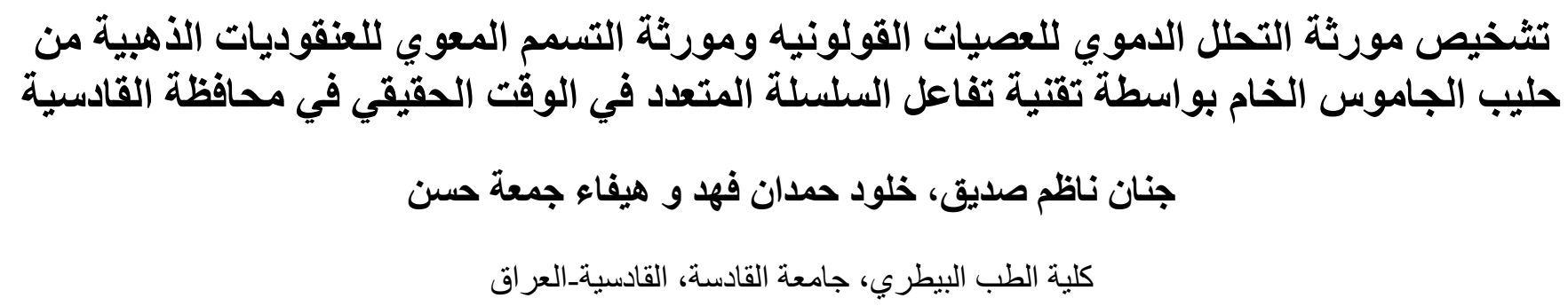

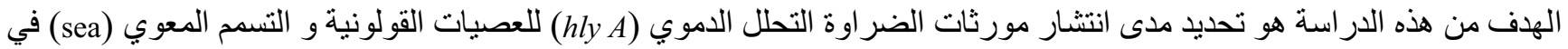

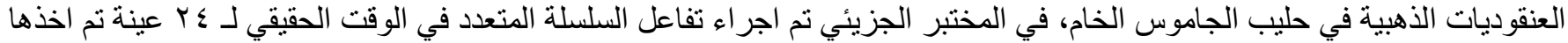

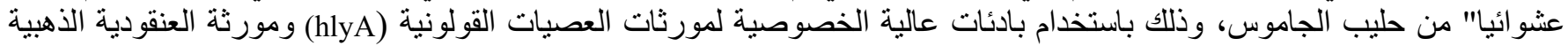

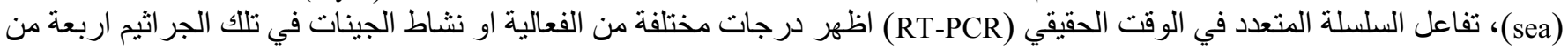

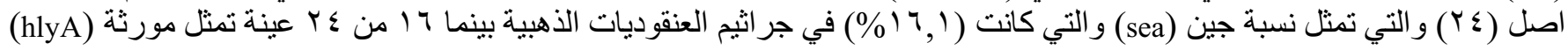

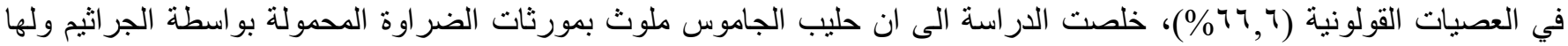
درجات مختلفة من النشاط.

\section{Introduction}

Raw milk is a good environment for the multiplication of many of bacteria like 'Salmonella spp, Campylobacter spp, Yersinia enterocolitis, Escherichia coli, and
Staphylococcus aureus' because the milk composed from many of nutrient element like protein - sugar -fat - mineral and etc (1).

The virulence genes is a sequence of nucleotide in DNA or plasmid of virus, fungi, and bacteria, it has specific 
code for creating virulence factor (proteins) that has a great role in the pathogenesis of the organism $(2,3)$.

S. aureus, Streptococcus spp and E. coli are a most common pathogen that lives in the milk of cow and buffaloes because they have one or more of virulence genes (4) The virulence genes transmitted among the organisms by two way, vertical way (by plasmid transmission) and horizontal way (second generation) $(5,6)$.

The gene hlyA and Sea are the most common virulence genes in E.coli and S.aureus respectively, The gene hlyA has the ability to produce active extracellular called cytotoxic hemolysin causing big, clear area of hemolytic around the colonies that formed on blood agar to absorb the iron from analytic blood, hemolysin secreted across membranes of bacteria and create a pore in the cell and affects erythrocytes (7-10). While sea gene in some of the strains of Staphylococcus aureus produces a protein called enterotoxin make the bacteria more virulence, it will increase significantly and severity of the infection (11).

Real time PCR is modern accurate assay to detection virulence genes used by several studies $(12,13)$.

The aim of this study was to investigate the prevalence some virulence genes in E.coli and S. aureus from raw milk in buffaloes and studying the activity of these genes by using Real Time PCR technique.

\section{Materials and methods}

\section{Sample collection}

Sample collection: Twenty-four samples of raw milk were collected randomly from buffaloes in different areas of the AL-Qadisiyah governorate transported directly to the laboratory of microbiology, of Veterinary Medicine faculty, University of AL- Qadisiyah All the samples were directly to the molecular assay of Real-Time PCR.

\section{Bacterial genomic DNA extraction}

Bacterial gDNA was prepared from E.coli and S. aureus samples by using PrestoTM Mini gDNA Bacteria Kit. Geneaid the USA). $1 \mathrm{ml}$ of overnight bacterial growth on Brian heart broth was put in (1.5) $\mathrm{ml}$ microcentrifuge tubes and then trans to centrifuge at (10000) rpm for 1 minute. After that, the supernatant was left and pellets of bacterial cells were used in gDNA, and the extraction was prepared according to company directions. Extracted gDNA was submitted to test of the Nanodrop spectrophotometer apparatus, and then kept at $-20 \mathrm{C}$ until performing RealTime PCR.

\section{Real-Time PCR}

Real-Time PCR technique was done for detecting the genes hlyA in E.coli isolates and Sea in S. aureus isolates. The primers were designed by using NCBI-GenBank recorded sequence by using primer 3 plus website designing. The primers were applied by company of Bioneer in Korea) Table (1).

Table 1: Sequence, Amplicon and Genebank code of used primer

\begin{tabular}{crlcc}
\hline Primer & \multicolumn{1}{c}{ Sequence } & Amplicon & GenBank \\
\hline \multirow{2}{*}{ Sea } & F & $\begin{array}{l}\text { GAGTTGGATCTTC } \\
\text { AAGCAAGACG }\end{array}$ & 91-bp & KT284332.1 \\
& R & $\begin{array}{l}\text { TTAATCCCCTCTG } \\
\text { AACCTTCCC }\end{array}$ & & \\
hlyA & F & $\begin{array}{l}\text { ATAAGCATGCTG } \\
\text { GTGAGTGC }\end{array}$ & & \\
& R & $\begin{array}{l}\text { TCTCTGCAACGTG } \\
\text { CTCAAAC }\end{array}$ & 88-bp & NC_012487.1 \\
\hline
\end{tabular}

The Real-Time PCR amplification reaction was done by using kit called (AccuPower ${ }^{\circledR}$ Green Star TMqPCRPreMix, from company of Bioneer in Korea) and the qPCR master mix was prepared for each sample according to company directions Table (2).

Table 2: Included volume of used solution in master mix solution

\begin{tabular}{lc}
\hline qPCR master mix & Volume \\
\hline Genomic DNA template & $5 \mu \mathrm{L}$ \\
Forward primer (10pmol) & $1 \mu \mathrm{L}$ \\
Reverse primer (10pmol) & $1 \mu \mathrm{L}$ \\
DEPC water & $13 \mu \mathrm{L}$ \\
\hline Total volume & $20 \mu \mathrm{L}$ \\
\hline
\end{tabular}

Next step these qPCR master mix components that mentioned in the table above was transferred into Green star qPCR premix standard plate tubes that contain the SYBER green dye and other PCR amplification components, then the plate mixed by Exispin by use vortex centrifuge for three minutes, then placed in MiniOpticon in Real-Time PCR system and applied settings of the thermocycler apparatus Table (3).

Table 3: Show temperature, time and repeat the cycle in all stage of PCR process

\begin{tabular}{lccc}
\hline qPCR step & Temperature & Time & $\begin{array}{c}\text { Repeat } \\
\text { cycle }\end{array}$ \\
\hline Initial Denaturation & $95^{\circ} \mathrm{C}$ & 3 minute & 1 \\
Denaturation & $95{ }^{\circ} \mathrm{C}$ & $10 \mathrm{sec}$ & \\
Annealing $\$ Extension & $60{ }^{\circ} \mathrm{C}$ & $30 \mathrm{sec}$ & 45 \\
Detection (scan) & $60-95^{\circ} \mathrm{C}$ & $0.5 \mathrm{sec}$ & 1 \\
Melting & & \\
\hline
\end{tabular}




\section{Results}

The total milk samples have taken from random buffaloes are twenty-four. All samples were tested by PCR by using two primers designed according to website NCBIGenBank and recorded sequence by using primer 3 plus design online for detection two genes, hly $A$ gene in E.coli and Sea gene in Staphylococcus aureus as a Table (4).

Table (4): Show results (percentage and number) of the genes that diagnostic by RT-PCR

\begin{tabular}{lcc}
\hline Samples & Positive & Percent (\%) \\
\hline S.aureus (Enterotoxin gene) & $4 / 24$ & $16.6 \%$ \\
E.coli (Hemolysin gene) & $16 / 24$ & $66.6 \%$ \\
\hline
\end{tabular}

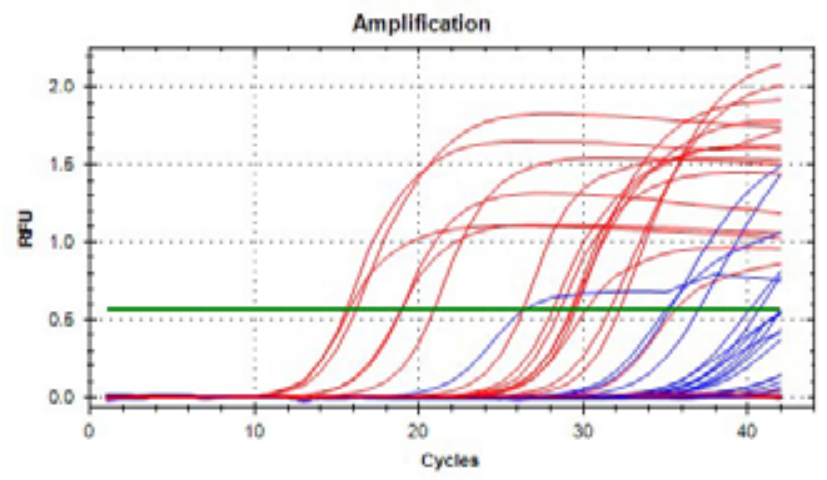

Figure 1: Real-Time PCR amplification plots for hemolysin gene in E. coli positive isolates (Red plot) and Enterotoxin gene in $S$. aurous positive isolates (Blue plot).

\begin{tabular}{|c|c|c|c|c|}
\hline Well $\diamond$ & Fluor $\diamond$ & Sample & $\begin{array}{l}\text { End } \diamond \\
\text { RFU }\end{array}$ & Call \\
\hline $\mathrm{AO4}$ & SYBR & Escherichia col & 1.93 & (+) Positive \\
\hline AO5 & SYBR & Escherichia col & 0.962 & (+) Positive \\
\hline BO4 & SYBR & Escherichia col & 2.04 & (+) Positive \\
\hline B05 & SYBR & Escherichia col & 1.07 & (+) Positive \\
\hline $\mathrm{CO} 4$ & SYBR & Escherichia col & 1.89 & (+) Positive \\
\hline $\cos$ & SYBR & Escherichia col & 0.811 & (+) Positive \\
\hline Do3 & SYBR & Staphylococcus & 1.11 & (+) Positive \\
\hline Do4 & SYBR & Escherichia col & 1.60 & (+) Positive \\
\hline Do5 & SYBR & Escherichia col & 1.45 & (+) Positive \\
\hline EO4 & SYBR & Escherichia col & 1.62 & (+) Positive \\
\hline E05 & SYBR & Escherichia col & 1.04 & (+) Positive \\
\hline F01 & SYBR & Staphylococcus & 0.773 & (+) Positive \\
\hline $\mathrm{FO} 3$ & SYBR & Staphylococcus & 1.30 & (+) Positive \\
\hline $\mathrm{FO} 4$ & SYBR & Escherichia col & 1.76 & (+) Positive \\
\hline Fos & SYBR & Escherichia col & 1.51 & (+) Positive \\
\hline $\mathrm{GO} 2$ & SYBR & Staphylococcus & 0.973 & (+) Positive \\
\hline Go4 & SYBR & Escherichia col & 1.75 & (+) Positive \\
\hline Go5 & SYBR & Escherichia col & 1.54 & (+) Positive \\
\hline $\mathrm{HO} 4$ & SYBR & Escherichia col & 1.21 & (+) Positive \\
\hline Ho5 & SYBR & Escherichia col & 1.66 & (+) Positive \\
\hline AO 1 & SYBR & Staphylococcus & 0.00565 & \\
\hline $\mathrm{AO} 2$ & SYBR & Staphylococcus & 0.310 & \\
\hline $\mathrm{A} 03$ & SYBR & Staphylococcus & 0.213 & \\
\hline A06 & SYBR & Escherichia col & 0.00593 & \\
\hline
\end{tabular}

Figure 2: Real-Time PCR endpoint data analysis of E.coli hemolysin gene and S. aurous Enterotoxin gene-positive isolates. 


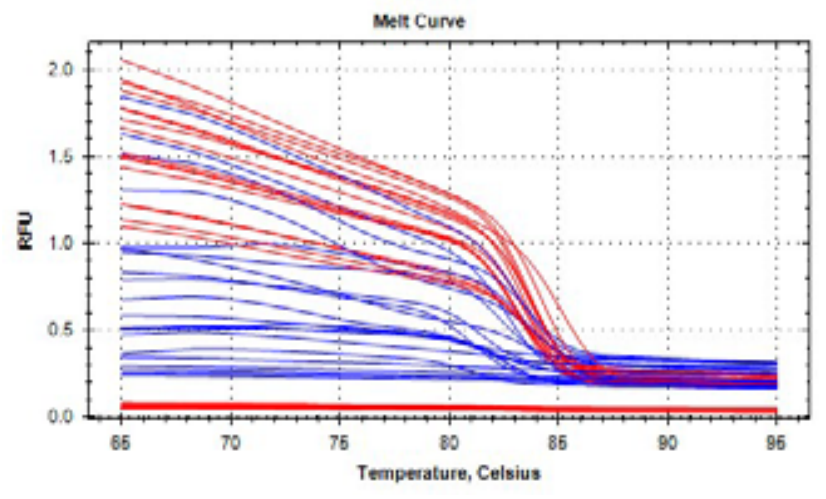

Figure 3: Real-Time PCR melt curve of E.coli hemolysin gene and $S$. aurous Enterotoxin gene-positive isolates.

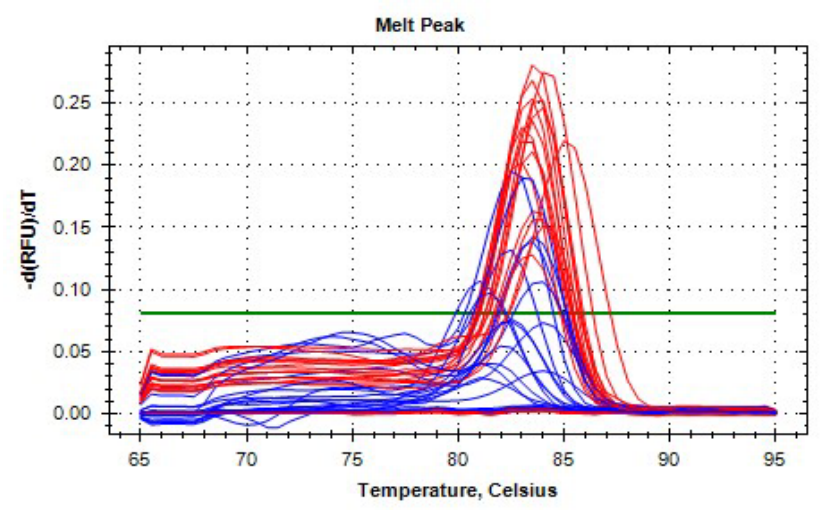

Figure 4: Real-Time PCR melt peak of E.coli hemolysin gene and $S$. aurous Enterotoxin gene samples that show primers specificity at approximately $84 \mathrm{C}$ melt peak.

\section{Discussion}

Many of the researchers studied virulence genes like sea and hlyA gene in Staphylococcus aureus and E.coli respectively by using RT-PCR technique and they found contrast degrees of activity of the genes (11-15).

Our results found the prevalence of hly A gene in E.coli that isolated from raw milk samples have taken from female buffalos was $(66.6 \%)$. In USA, the prevalence of hly A gene in E.coli was $63 \%(12)$, and in Spain was $56 \%(15)$ that considered very close to our results and support our study. While in Iran (16) In Spain (17) and in Egypt (18) found the prevalence of hly $A$ gene that isolated from E.coli from raw milk of buffaloes were $(23 \%),(35 \%)$, and $(50.2 \%)$ respectively; all above represent less than the value of our results. Many of studies recorded the prevalence of hly $A$ gene in E.coli more than our rates like (19) where record $(71.3 \%)$ in Canada.
Our results found the prevalence of hly $A$ gene in E.coli that isolated from raw milk samples have taken from female buffalos was $(66.6 \%)$. In USA, the prevalence of hly A gene in E.coli was 63\% (12), and in Spain was 56\% (15) that considered very close to our results and support our study.

While in Iran (16) In Spain (17) and in Egypt (18) found the prevalence of $h l y A$ gene that isolated from E.coli from raw milk of buffaloes were (23\%), (35\%) and $(50.2 \%)$ respectively; all above represent less than the value of our results.

Many of studies recorded the prevalence of hly $A$ gene in E.coli more than our rates like (19) where record (71.3\%) in Canada.

The prevalence of virulence genes of E.coli recorded in summer more than winter and other seasons, that means the season has strong relationship with the prevalence, there are significant differences in rate distributions of virulence genes in E.coli were observed milk samples taken in different seasons also from different areas, it has different values of hlyA gene; however, significantly higher rates were found in cow and buffalo, also depend on the type and virulence of the strain (13).

Our results found the prevalence of Sea gene in Staphylococcus aureus that isolated from raw milk samples has taken from buffalos was $(16.6 \%)$, that agreement with results of (20) in Germany where it was (15.9\%). Furthermore, results of (21) also agree with our results in Germany was the most frequent $(17.4 \%)$ of Enterotoxin gene. While (22) recorded rate more than our results where he found the percentage of seA gene in Staphylococcus aureus was (46\%) in Iran - Tehran. also, Sea gene was $(69.6 \%)$ by (23) in France that isolated the gene from Staphylococcus aureus has taken from food poisoning, (24) confirm prevalence less than our results were record $(15.4 \%)$.

Causes of different the rates among the studies depend on several factors; $s e A$ gene was significantly related with the severity of the disease, SEA protein will increased expression of inflammation mediators (25). Mohammad and coworkers (2009) Found the percentage of $S$. aureus carrying sea gene depends on the type and degree of the infection.

This is due to many differences in the prevalence rate of sea gene and differant degree of activities in different studies. However, we should consider that detection of seA genes is not always concurrent with the toxin production, this may be due to a lower level of toxin productions or mutations in regulatory regions even in one strain (26).

At the end, the virulence genes distributed at different in the values and the activation and related with the organism and the environment around. 


\section{References}

1. Pauline M, van Diemen PM, Francis Dziva FI, Mark P, Stevens MP, Timothy S Wallis Identification of enterohemorrhagic Escherichia coli $\mathrm{O} 26: \mathrm{H}-$ Genes Required for Intestinal Colonization in Calves. Infect Immun. 2005;73(3):1735-1743.

2. Bai J, Shi X, Nagaraja TG. A multiplex PCR procedure for the detection of six major virulence genes in Escherichia coli. J Microbiol Methods. 2010;82:85-89.

3. Gordillo, R., C ordoba, J.J., Andrade, M.J., Luque, M.I. and Rodr_1guez, M. (2011) Development of PCR assays for detection of Escherichia coli in meat products. Meat Sci 88, 767-773.

4. Paton JCAW Paton. Pathogenesis and diagnosis of Shiga toxin producing Escherichia coli infections. Clin Microbiol Rev. 1998; 11:450-479.

5. Dziva FI, van Diemen PM, Stevens MP, Smith AJ, Wallis TS. Identification of Escherichia coli O157: H7 genes influencing colonization of the bovine gastrointestinal tract using signature-tagged mutagenesis. Microbiol. 2004;11:3631-45.

6. Buchanan RL, Doyle MP. Foodborne disease significance of Escherichia coli $0157: \mathrm{H} 7$ and other enterohemorrhagic $E$ coli. Food Technol. 1997;51(10):69-76.

7. Bhakdi S, Greulich S, Muhly M, Eberspacher H, Becker A. Thiele T, Hugo F. Potent leukocidal action of Escherichia coli hemolysin mediated by permeabilization of target cell membranes. J Exp Med. 1989;169:737- 754.

8. Bhakdi S, Muhly M,. Korom S, Schmidt G. Effects of Escherichia coli hemolysin on human monocytes. Cytocidal action and stimulation of interleukin 1 release. J Clin Investig. 1990;85:1746-1753.

9. Wiles TJ, Kulesus RR, Mulvey MA. Origins and virulence mechanisms of uropathogenic Escherichia coli. Exp Mol Pathol. 2008;85:11-9

10. Monika K, Heather E. Allison, Istva'n Ba'tai, $\mathrm{A}^{\prime}$ gnes Sonnevend, Levente E, No'ra P, and Tibor P. Occurrence of hlyA and sheA Genes in Extraintestinal Escherichia coli Strains. J Clini Micrbiol. 2005;43:2965-2968.

11. Tristan F, Damien T, Anne-Laure G, Miche` le B, Gerard L, Franc ois $\mathrm{V}$, Jerome E. Comparative Prevalence of Superantigen Genes in Staphylococcus aureus Isolates Causing Sepsis With and Without Septic Shock.france. Centre National de Re'fe'rence des Staphylocoques, INSERM, Lyon, France. Clini Infect Dis. 2005;41:771-7.

12. Karns JS, Van Kessel JS, McClusky BJ, Perdue ML. The incidence of Escherichia coli O157:H7 and E. coli Virulence Factors in US Bulk Tank Milk as Determined by Polymerase Chain Reaction. American Dairy Science Association. J Dairy Sci. 2007;90:3212-3219.

13. Ebrahim R, Faham K, Farzad Y, Hassan M. Isolation and Characterization of Enterohaemorragic Escherichia coli O157:H7 and EHEC O157:NM from Raw Bovine, Camel, Water Buffalo, Caprine and Ovine Milk in Iran. Kafkas Univ Vet Fak Derg. 2012;18(4):559564.
14. Farshad S, Emamghorashi F. The prevalence of virulence genes of E. coli strains isolated from children with urinary tract infection. Saudi J Kidney Dis Transpl. 2009;20(4):613-617.

15. Blanco J, Blanco M, Blanco JE, Mora A, Gonzalez NA, Bernardez MI, Alonso MP, Coira A, Rodriguez A, Rey J, Alonso JM, and Usera S. Verotoxin-Producing Escherichia coli in Spain: Prevalence, Serotypes, and Virulence Genes of 0157H7 0157:H7 and Non-0157 VTEC in Ruminants, Raw Beef Products, and Humans. Soci Experi Biol and Med. 2003.

16. Yaghobzadeh N, Ownagh A, Mardani K, Khalili M. Prevalence, molecular characterization and serology of Shiga toxin producing Escherichia coli isolated from buffaloes in West Azerbaijan, Iran. Int J Vet Res. 2011;5:113-117.

17. Blanco J, Blanco M, Blanco JE, Mora A, Alonso MP, Gonzalez EA, Bernardez MI. Epidemiology of verocytotoxigenic Escherichia coli (VTEC) in ruminants. In: Duffy G. Garvey P. McDowell DA. Eds. Verocytotoxigenic E. coli. Trumbull. CT: Food and Nutrition Press. ppl13-148.2001.

18. El-Jakee JK, Mahmoud RM, Samy AA, Mona A. El-Shabrawy MM, Gad El-Said WA. Molecular Characterization of E. coli Isolated from Chicken, Cattle and Buffaloes. Intern J Microbiol Res. 2012;3(1):6474.

19. Gehua W, Clifford G C, Frank GR. Detection in Escherichia coli of the Genes Encoding the Major Virulence Factors, the Genes Defining the O157:H7 Serotype, and Components of the Type 2 Shiga Toxin Family by Multiplex PCR. J Clin Microbiol. 2002;40:3613-3619

20. Karsten B, Alexander W, Friedrich E, Gabriele L, Maria W, Georg P, Christof von E. Prevalence of Genes Encoding Pyrogenic Toxin Super antigens and Exfoliative Toxins Among Strains of Staphylococcus aureus Isolated from Blood and Nasal Specimens. J Clin Microbiol. 2003; 143:4-1439

21. Borst DW, Betley MJ. Phage-associated differences in staphylococcal enterotoxin A gene (sea) expression correlate with sea allele class. Infect Immun. 1994;62(1):113-8.

22. Mohammad RP, Mojtaba M, Mostafa H, Sahar B Y. High Prevalence of sea Gene Among Clinical Isolates of Staphylococcus aureus in Tehran. Tehran University of Medical Sciences. Acta Medica Iranica. 2009;47(5):357-361.

23. Kérouanton A, Hennekinne JA,. Letertre C, Petit L, Chesneau OL, Brisabois A, De Buyser ML. Characterization of Staphylococcus aureus strains associated with food poisoning outbreaks in France. Intern J Food Microbiol. 2007;115:369-375

24. Naffa RG, Bdour SM, Migdadi HM and Shehabi AA. Enterotoxicity and genetic variation among clinical Staphylococcus aureus isolate in Jordan. J Med Microbiol 2006;55(Pt 2):183-7.

25. Dongli Rong1, Qingping Wu, Mingfang Xu, Jumei Zhang and Shubo Yu. Prevalence Virulence Genes‘Antimicrobial Susceptibility, and Genetic Diversity of Staphylococcus aureus from Retail Aquatic Products in China. Front Microbiol. 2017; www.frontiersin.org Volume 8 Article 714.

26. Sharma NK, Rees CE, Dodd CE. Development of a single reaction multiplex PCR toxin typing assay for Staphylococcus aureus strains. Appl Environ Microbiol. 2000;66(4):1347-53. 